Commentary

\title{
Religion, Gender, and Social Welfare: Considerations Regarding Inclusion
}

\author{
Susan Crawford Sullivan \\ Department of Sociology and Anthropology, College of the Holy Cross, Worcester, MA 01610, USA; \\ E-Mail: ssulliva@holycross.edu
}

Submitted: 5 June 2019 | Accepted: 5 June 2019 | Published: 24 June 2019

\begin{abstract}
There is increased interest in faith-based social service provision in recent years, both in the United States and across Europe. While faith-based organizations provide welcome and needed services, there are several potential problems of social inclusion which involve gender, including decreased availability of social services when faith-based organizations are expected to compensate for cuts in government spending, potential for religious discrimination in employment, and potential for religious discrimination against recipients.
\end{abstract}

\section{Keywords}

gender; inclusion; religion; social welfare

Issue

This commentary is part of the issue "Exhausted Women-Exhausted Welfare: Understanding Religion, Gender and Welfare in Social Inclusion", edited by Martha Middlemiss Lé Mon (Uppsala University, Sweden).

(C) 2019 by the author; licensee Cogitatio (Lisbon, Portugal). This article is licensed under a Creative Commons Attribution 4.0 International License (CC BY).

\section{Introduction}

In recent years there has been increased interest in faithbased social service providers across the United States and Europe, including the Nordic states (Baker, 2012; Rommelspacher, 2017). Drawing on my background as a sociologist of religion studying the United States, I aim to raise questions about religious social services and social inclusion, urging readers to consider how they may translate to a Nordic context despite differing approaches to social welfare and religion.

Even in a more secular era, $90 \%$ of American adults say they believe in a higher power and $38 \%$ claim to attend religious services weekly or almost weekly (Fahmy, 2018; Newport, 2018). 83\% of congregations, comprising $92 \%$ of service attendees, provide assistance to people outside the congregation, most often short-term assistance for food or clothing (Chaves \& Eagle, 2016, p. 54). Large religious non-profit organizations receive a substantial portion of their funding from the government and are among the major human service providers in the United States. Public policy in the past two decades has demonstrated increased emphasis on faith-based social service provision.
According to Birgit Rommelspacher (2017), although church membership and attendance is declining in Europe, faith-based social service agencies have become more numerous. Rommelspacher (2017) claims that despite critique of religion, the services of faith-based organizations are welcomed by people, while politicians appreciate their "economic advantages" and "their image of offering more personally-motivated services" (Rommelspacher, 2017, p. 799). She notes how churches provide more than half of social services in Germany (with Christian social welfare organizations employing over 1 million people) and notes that faith-based social services have greatly expanded in Sweden as public welfare expenditure has decreased (Rommelspacher, 2017). Christopher Baker (2012, p. 6) similarly claims that in England, "millions of pounds of government money [are] being pumped into helping faith groups become 'service provider' ready".

"Faith-based social service provision" is broad, ranging from individual congregational volunteers to large professional organizations. It also ranges in intensity of religion in the operations of social service provisionfrom none to extremely intense (Rommelspacher, 2017). Women make up the majority of congregational volun- 
teers, professional service providers, and service recipients (Edgardh, 2011).

Regarding social inclusion, there are several issues which have arisen in the United States that can translate to Nordic countries: (1) If faith-based organizations are expected to compensate for cuts in government spending, there is a fundamental question of social inclusionwill all who need services receive them? (2) If faith-based social service providers can discriminate in employment, social exclusion of some applicants or employees will occur, and (3) Social exclusion also arises when organizations can discriminate against potential recipients. Gender issues are salient in all of these questions.

\section{Recent Policy Background on Religion and Social Welfare Provision in the United States}

Religious organizations have long been involved in social service provision in the United States, through smallscale efforts in congregations to large religious nonprofit organizations (Hall, 2016). Political and scholarly interest in faith-based provision of social services intensified after the 1996 welfare reform law, which contained a clause encouraging partnerships between religious organizations and government in service provision. While partnerships between religious service organizations and government had previously existed for decades, religious organizations had to set up separate non-profit organizations that did not display religious symbols, and they could not discriminate in hiring on the basis of religion (Cnaan \& Boddie, 2002). Under the new law, religious symbols and principles were permitted in programs receiving government money, which could hire staff using religious criteria. Individual congregations were permitted to apply for government funds to support social services (but not religious activities); proselytizing and rejecting recipients on the basis of religion were prohibited. Recipients also had the right to have alternative non-religious providers available (Cnaan \& Boddie, 2002). In 2001, then-President Bush established the White House Office of Faith-Based and Community Initiatives to further develop religious partnerships. Numerous states, cities, and federal agencies developed their own faith-based offices. Executive orders controversially exempted religious organizations from non-discrimination clauses in hiring (Wright, 2009). Scholars note that the Clinton/Bush era laws did not result in largely increased partnerships between government and faith organizations. According to Peter Dobkin Hall:

The debate over charitable choice stemming from the welfare reforms of the mid-1990s was not so much an argument about church-state separation as it was an effort to codify government support for faith-based social services that had been a feature of America's human services regime for decades. (Hall, 2016, p. 23)
Former president Obama continued to work with faith communities, renaming the office the White House Office of Faith-Based and Neighborhood Partnerships. He created a faith advisory council composed of clergy of different backgrounds and non-profit leaders to provide advice on policy priorities; partnership offices also worked in 13 federal agencies (White House Archives, n.d.).

In 2018, President Trump announced an executive order replacing the Obama era office with a new White House Faith and Opportunity Initiative, saying:

This office will also help ensure that faith-based organizations have equal access to government funding and the equal right to exercise their deeply held beliefs. We take this step because we know that, in solving the many, many problems and our great challenges, faith is more powerful than government, and nothing is more powerful than God. (White House Briefings, 2018)

The executive order allows every department to incorporate partnerships with faith communities. It removes language requiring alternate service providers be made available for people who do not desire a faith-based service provider as well as raises concerns about potential for discrimination against LGBTQ persons and others (Levine, 2018).

\section{Conclusion: Services, Gender, and Social Inclusion}

Returning to the three issues posed at the beginning of this commentary, it is clear that while religiouslyaffiliated social service provision is an important part of social welfare, it is wise to be attentive to potential for social exclusion. Despite differing social welfare contexts, these concerns extend beyond the United States to Europe, including the Nordic countries.

Most fundamentally, religious social service providers do not have the capacity to substantially replace the role of government (Green, 2017). The notion that "faith is more powerful than government, and nothing is more powerful than God" cited above in President Trump's 2018 remarks, coupled with his proposed drastic budget cuts to human services, points to a notion that religious institutions should have an increased role in providing services in light of decreased governmental provision-a notion also occurring in Europe. However, large religious non-profits in the United States receive substantial percentages of their funding from the government, while individual congregations provide needed services but at small scales (Chaves \& Eagle, 2016). Social exclusion, then, will occur when people are denied needed services. Ninna Edgardh states that "women will suffer disproportionately from any diminution in the role of the state as responsible for the welfare of the citizens" (Edgardh, 2011, p. 64). Some women will suffer as recipients losing services, while some will suffer overwhelming 
care burdens as default presumed caregivers of family members (Edgardh, 2011). For my book, Living Faith: Everyday Religion and Mothers in Poverty, I interviewed urban women in extreme poverty. While appreciating the good that religious social services do, many women raised concerns. Said one:

I think that they [churches] do what they can do, but they have a lot of limitations as far as funds and raising money....Every church I know helps people with food banks, clothing drives, or things like that. I think they do a lot, and I think the government should be doing more. (Sullivan, 2011, p. 222)

Second, faith-based service providers in the United States can legally use religious preferences in hiring. Large religiously-affiliated professional social service nonprofits hire from all religions and none. However, religious organizations are permitted to use hiring preferences, even if financially partnering with government. While laws permitting religious hiring preferences are designed to allow religious social service providers to retain their core identity, in practice it is necessary to be attentive to potential for social exclusion. Gender issues arise here in that employees are primarily women (paid social service work is primarily provided by women in both the United States and Europe; see Edgardh, 2011), as well as because of potential for discrimination due to sexual orientation. Discrimination concerns have impacted Europe as well, as Josef Hien (2017) details in a discussion of employment discrimination by faith-based welfare providers in Germany, where $80 \%$ of social care workers are female. Hien describes cases of people who lost their jobs due to "morally and socially conservative" faith-based welfare organizations, legally exempt from labor discrimination laws, disapproving of employees' lifestyles (such as having a same-sex partner; Hien, 2017, p. 535).

Third, in the United States, recent changes have brought concerns regarding discrimination against recipients, prohibited for organizations partnering with government in earlier laws (Cnaan \& Boddie, 2002). While large professionalized religious nonprofits do not discriminate against recipients by religion, this may not hold true for all types of faith-based providers. Furthermore, recipients are no longer required to receive information about alternative secular organizations. Gender issues are salient, as substantial concerns have been raised regarding discrimination against LGBTQ populations (Levine, 2018). Even without active discrimination, exclusion may still occur, as noted by the women in poverty I interviewed who feared that people unaffiliated with religion would have less access to social services: "There's people who don't have a church home...so what happens to those people? The services wouldn't be spread among the people equally" (Sullivan, 2011 , p. 222). Finally, some types of faith-based service providers promote conservative gendered views which may not be beneficial to recipients. For example, Rachel Ellis (2018) found in research on prison ministry to female inmates that Christian and Muslim volunteers encouraged inmates to find a religious husband and be submissive to him.

To conclude, in both the United States and Europe, governments are looking to faith communities as possible sources of increased social service provision, sources viewed as less expensive and more personal. Despite the welcome and needed social services that congregational volunteers and faith-based organizations provide to their communities, it is necessary to remain alert to issues of social inclusion-especially as they relate to gender.

\section{Acknowledgments}

I am grateful for financial support for part of this work from the Women's Studies in Religion Program (WSRP) at Harvard Divinity School, the Louisville Institute, Harvard Kennedy School, and the College of the Holy Cross.

\section{Conflict of Interests}

The author declares no conflict of interests.

\section{References}

Baker, C. (2012). Spiritual capital and economies of grace: Redefining the relationship between religion and the welfare state. Social Policy and Society, 11(4), 565-576. https://doi.org/10.1017/ S1474746412000279

Chaves, M., \& Eagle, A. (2016). Congregations and social services: An update from the third wave of the National Congregations Study. Religions, 7(5). https:// doi.org/10.3390/rel7050055

Cnaan, R. A., \& Boddie, S. C. (2002). Charitable choice and faith-based welfare: A call for social work. Repository University of Pennsy/vania. Retrieved from http:// repository.upenn.edu/spp_papers/6

Edgardh, N. (2011). A gendered perspective on welfare and religion in Europe. In A. Bäckström, G. Davie, N. Edgardh, \& P. Pettersson (Eds.), Welfare and religion in the 21st century Europe. Volume 2: Gendered, religious and social change (pp. 61-106). Farnham: Ashgate.

Ellis, R. (2018). "It's not equality": How race, class, and gender construct the normative religious self among female prisoners. Social Inclusion, 6(2), 181-191. https://doi.org/10.17645/si.v6i2.1367

Fahmy, D. (2018, April 25). Americans' belief in God: Key findings. Pew Research. Retrieved from https://www.pewresearch.org/fact-tank/2018/04/ 25/key-findings-about-americans-belief-in-god

Green, E. (2017, March 26). Can religious charities take the place of the welfare state? The Atlantic. Retrieved from https://www.theatlantic.com/politics/archive/ 2017/03/budget-religion/520605/2017 
Hall, P. D. (2016). Historical perspectives on nonprofit organizations in the United States. In D. O. Renz \& R. D. Herman (Eds.), The Jossey-Bass handbook of nonprofit leadership and management (pp. 3-33). Hoboken, NJ: John Wiley \& Sons.

Hien, J. (2017). From private to religious patriarchy: Gendered consequences of faith-based welfare provision in Germany. Politics and Religion, 10(3), 515-542. https://doi.org/10.1017/s1755048317000086

Levine, M. (2018, May 7). Will Trump's new faithbased initiative increase services or discrimination? Non Profit Quarterly. Retrieved from https://nonprofitquarterly.org/2018/05/07/

will-trumps-new-faith-based-initiative-increaseservices-discrimination

Newport, F. (2018, September 7). Church leaders and declining religious service attendance. Gallup. Retrieved from https://news.gallup.com/opinion/ polling-matters/242015/church-leaders-decliningreligious-service-attendance.aspx\#main

Rommelspacher, B. (2017). Religion and welfare. Euro- pean Journal of Social Work, 20(6), 795-800. https:// doi.org/10.1080/13691457.2017.1318262

Sullivan, S. C. (2011). Living faith: Everyday religion and mothers in poverty. Chicago, IL: University of Chicago Press.

White House Archives. (n.d.). About the Office of Faithbased and Neighborhood Partnerships. Obama White House Archives. Retrieved from https:// obamawhitehouse.archives.gov/administration/ eop/ofbnp/about

White House Briefings. (2018). Remarks by President Trump at the National Day of Prayer. White House. Retrieved from https://www.whitehouse.gov/ briefings-statements/remarks-president-trumpnational-day-prayer

Wright, D. (2009, June 11). Taking stock: The Bush Faith-Based Initiative and what lies ahead. Albany, NY: The Nelson A. Rockefeller Institute of Government. Retrieved from http://research.policyarchive. org/20306.pdf

\section{About the Author}

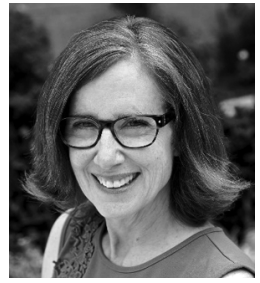

Susan Crawford Sullivan is Associate Professor of Sociology at the College of the Holy Cross in Worcester, MA. She has also been a Visiting Assistant Professor and Research Associate at Harvard Divinity School's Women's Studies in Religion Program. She researches and teaches at the intersection of religion, family, poverty, and public policy. Her book Living Faith: Everyday Religion and Mothers in Poverty (University of Chicago Press, 2011) won the 2012 Distinguished Book Award from both the American Sociological Association Sociology of Religion section and the Society for the Scientific Study of Religion. 